$\xi_{\mathrm{p}}$

\title{
A Case Study of Undergraduate Students Computer Self-Efficacy from Rural Areas
}

\author{
Rajermani Thinakaran ${ }^{1}$, Rosmah $\mathrm{Ali}^{2}$, Wan Nor Al-Ashekin Wan Husin ${ }^{3}$ \\ ${ }^{1,3}$ Dept. of Comp., Faculty of Science and Technology, \\ Nilai University, Negeri Sembilan Malaysia \\ ${ }^{2}$ Advanced Informatics School, UTM International Campus' \\ Kuala Lumpur, Malaysia \\ *Corresponding Author Email: rajermani@nilai.edu.my
}

\begin{abstract}
In students' learning process, self-efficacy plays an important part. In Malaysia, there are a number of researches on students' self-efficacy. However, none of the studies focuses on undergraduate students' computer self-efficacy from the rural areas. This article presents a quantitative research on undergraduate students' perceived computer self-efficacy. A total of 128 first semester undergraduate students participated in the survey, employing a 27 -item questionnaire measuring computer self-efficacy. The items were pilot-tested before being administered to the respondents. Outcome of the research show that computer self-efficacy level is high for basic and advanced skills. The result of the research shows that rural community has accepted the ICT as part of their lifestyle.
\end{abstract}

Keywords: Computer Self-Efficacy, Computer Skills, Rural Arrears, Undergraduate Students.

\section{Introduction}

In students' learning process self-efficacy plays an important role [29]. Albert Bandura, a recognized Canadian psychologist defined self-efficacy as "people's judgment of their capabilities to organize and execute sequences of actions required to attain chosen types of performance. It is concerned not with the skills one has but with judgment of what one can do with whatever skills one possesses" [3].

Miura [21] has recommended that self-efficacy is a fundamental feature to achieve computing skills. From the self-efficacy theory, computer self-efficacy has been derived where a student's perceived ability to use a computer. Kinzie and Delcourt [19] defined computer self-efficacy as a measure of how confident the student is with their capability to understand, use, and apply computer knowledge and skills. The authors found that students who have high computer self-efficacy will feel competent in using diverse computer hardware and software. Conversely, low computer selfefficacy leads to the belief that student will meet struggles in using computers hardware and software.

There are a number of researches on students' self-efficacy and students' computer self-efficacy in Malaysia, for examples selfefficacy in learning English [20], self-efficacy in general learning [29], self-efficacy in academic achievements and performances [2][9], computer self-efficacy towards internet [27] and computer self-efficacy among accounting educators [7]. Next, there are many research on ICT (Information and Communication Telecommunication) knowledge level of rural area communities, for examples, adult computer literacy level [18], students' skills toward ICT [11][17], and digital inequalities between the rural and urban [15].

However, none of the studies focuses on undergraduate students' computer self-efficacy from the rural areas. Therefore, this present study focuses on students' self-efficacy in computer skills in higher institutions from rural areas. It is hoped that this study will add to the literature in this area.

\section{Literature Review}

\section{A. ICT in Rural Areas}

Although there are numerous researches done in rural education, educators across the world have not come to an agreement as to the meaning of rural. Different researchers have a different definition about the rural concept. A definition given by Ibrahim [14] which suits well in this study is "rural as the area outside urban including settlements with a population less than 10,000 people, within the agriculture area, forest area or water bodies". Malaysia is one of the most progressive developing countries in the world and has been promoting the usage of ICT to its citizens. However, there are many challenges that Malaysia has to face in order for the country to be able to fully utilize the usage of ICT by all of its citizens.

In Malaysia, a study done by Noor Sharifah [24], discovered that computer owned among rural community is generally limited. From 1,652 household surveys, the author found that only $18.6 \%$ owned a computer. Another researcher, Musa [23], supported this fact. The 
researcher stated that the main problem that caused low ICT usage is the ability to use ICT. Abu Samah et al. [1] said that rural community were still lacking in ICT knowledge and skills particularly in computer usage. According to this author and his cliques there are several reasons why rural communities have less awareness to this matter. The reasons are listed in Table 1.

Table 1. Reasons of less awareness to use ICT by Rural Communities Less Awareness to Use ICT Due to

1. Lack of ICT skills and knowledge.

2. Not knowing the benefit of ICT.

3. Lack of support from government and private agencies.

4. Lack of time to use ICT.

5. Lack understanding and consciousness regarding ICT importance.

6. Low budget on ICT equipment.

7. Internet service is not available in their area and language problems.

8. Irrelevant ICT contents.

9. ICT not user friendly.

\section{B. ICT Implementation in Rural Areas}

From the stated reason by the authors [1][23-24][27], there is a solution. Since 1957 rural development evolution and transformation has started with equity development of the New Economy prepolicy.

From1994 to 2020, the second era of revolution focused on rural development to achieved balance development according to the State Vision Policy [27]. One of the policies is to make ICT literacy among the rural community. To achieve this objective, numerous efforts have been introduced by the Malaysian government which is:

1. The National Information and Technology Agenda (NITA) - launched by Tun Dr. Mahathir Mohamad former prime minister in 1996. NITA was introduced in order to promote and strengthen ICT awareness and usage particularly the rural community [27].

2. Rural Internet Center - also known as PID (Pusat Internet Desa). PID projects started by Ministry of Information Communication and Culture (MICC) in 2000. The project is responsible in filling the gap that occurs between the rural and urban community in term of ICT usage, skills and knowledge. Among the services offered were ICT training in computer applications, e-mail usage and website surfing [9].

3. Rural Info Center - known as MID (Medan Info Desa). This project was set-up through Infodesa by the Ministry of Rural and Regional Development (MRRD). The key objective is to expose ICT facilities and conduct basic ICT trainings to the rural community. Among the services offered are training on basic and advanced computer skills, computer and internet services, Infodesa portal, printing, website services, computer repair and information on villages nationwide [9].

4. Village WiFi services - known as Kampung Tanpa Wayar (KTW). Implemented by the MCMC under the National Broadband Initiative (NBI) and is funded through the Universal Service Provision (USP) fund which is implemented by the selected telecommunication service provider since 2007 [28].

\section{Computer Self-Efficacy}

Learning efficacy also called self-efficacy refers to what a student believes which can be done in a particular learning task. Self-efficacy theory relies on the beliefs of four sources of information which are choice of activities, level of effort being expended, persistence in the face of difficulties and performance [3]. Students tend to have some self-efficacy beliefs. That is, they hold some opinions about their ability in relation to the specific learning domain. They also hold some outcome expectations (opinions they hold about the success or failure of specific actions). For example, a student might want to use computer to perform some task with the view that: "I tend to find computer is difficult to operate (selfefficacy belief) so I am likely to need a lot of help to complete the task (outcome expectation)". These beliefs tend to act as a frame of reference that guide students' thinking, feelings and actions in a learning situation. Adapted from the self-efficacy theory, computer self-efficacy is an individual's ability to use a computer.

\section{Methodology}

The purpose of this study is to identify undergraduate students' computer self-efficacy from a rural environment. A quantitative survey approach is adapted for this research.

\section{Instrument}

A questionnaire was used to answer research questions. In many evaluations, a questionnaire aids as the main source of information which can be tabulated and discuss. There are many instruments that have been developed to evaluate computer self-efficacy [46][13][19][22][30]. To select an appropriate computer self-efficacy instrument, the researcher needs to identify which computer skills need to be measured [25].

Murphy et. al. [22], developed a 32-item instrument for computer self-efficacy based on Banduras' (2002) work. The instrument consist three features which are "beginning level computer skills", "advanced level computer skills" and "mainframe computer skills". The instrument was validated and the reported Cronbach's alpha for the three derived features was .97, .96, and .92. Torkzadeh and Koufteros [30] recommended four features of 30-item adapted from Murphy et al. [22]. In the recommended instrument "file and software skills" was added. The instrument was validated with an oblique rotation and reported the reliability for each as $.94, .96, .90$, .91 respectively.

In this study, both scales [22][30] have been adapted. The adapted instrument comprises two parts, demographic and 27-items to which discovering students' computer self-efficacy where each item is preceded by the phrase "I feel confident". This 27 -items had two sub-categories, basic skills (13 items) and advanced skills (14 items). The strength of self-efficacy is measured by responses on a 5 point Likert type scale ranging from 1 (not confident at all) to 5 (absolutely confident). The score obtainable from the scale is in the range of the minimum 27 and the maximum of 135 points. The indication of student computer self-efficacy identifies as low, average and high. The range of student self-efficacy is shown in Figure 1. High scores indicate respondents' high levels of selfefficacy in using computers and vice-versa. 


\begin{tabular}{|c|c|c|}
\hline \multicolumn{3}{|c|}{ Overall Self-Efficacy } \\
\hline Low & Average & High \\
\hline $27-62$ & $64-99$ & $100-135$ \\
\hline \multicolumn{3}{|c|}{ Basic Skills } \\
\hline Low & Average & High \\
\hline $13-29$ & $30-47$ & $48-65$ \\
\hline \multicolumn{3}{|c|}{ Advanced Skills } \\
\hline Low & Average & High \\
\hline $14-32$ & $33-51$ & $52-70$ \\
\hline
\end{tabular}

Figure 1. Students' Computer Self-Efficacy Level

\section{E. Instrument Validity and Reliability}

A questionnaire must be validated to make sure that it accurately measures what it is supposed to do, regardless of the responder [8]. Valid questionnaire helps to collect better quality data with high comparability which reduces the effort and increase the reliability of data. The designed instrument has been validated using content and face validation.

Content validation in any tool says how well the individual items in the tool correspond to the concept of what are being examined. The designed instrument was given and reviewed by four Information Technology (IT) lecturers according to the validation criteria.

\begin{tabular}{|c|c|c|c|c|c|c|}
\hline $\begin{array}{c}\text { Content Validation } \\
\text { Criteria }\end{array}$ & L1 & L2 & L3 & L4 & L5 & CVI \\
\hline $\begin{array}{l}\text { 1. The objective of } \\
\text { the instrument is } \\
\text { stated clearly. }\end{array}$ & $\checkmark$ & $\checkmark$ & $\checkmark$ & $\checkmark$ & $\checkmark$ & 1.00 \\
\hline $\begin{array}{l}\text { 2. The format is } \\
\text { appropriate. }\end{array}$ & $\checkmark$ & $\checkmark$ & $\checkmark$ & $\checkmark$ & $\checkmark$ & 1.00 \\
\hline $\begin{array}{l}\text { 3. The font size is } \\
\text { appropriate. }\end{array}$ & $\checkmark$ & $\checkmark$ & $\checkmark$ & $\checkmark$ & $\checkmark$ & 1.00 \\
\hline $\begin{array}{l}\text { 4. The meaning of } \\
\text { every item is clear. }\end{array}$ & $\checkmark$ & $\checkmark$ & $\checkmark$ & $\checkmark$ & $\checkmark$ & 1.00 \\
\hline $\begin{array}{l}\text { 5. The instruction is } \\
\text { clear. }\end{array}$ & $\checkmark$ & $\checkmark$ & $\checkmark$ & $\checkmark$ & $\checkmark$ & 1.00 \\
\hline $\begin{array}{l}\text { 6. The measurement } \\
\text { scale is } \\
\text { appropriate. }\end{array}$ & $\checkmark$ & $\checkmark$ & $\checkmark$ & $\checkmark$ & $\checkmark$ & 1.00 \\
\hline Average CVI & & & & & & 1.00 \\
\hline
\end{tabular}

L - Lecturer

Figure 2. Content Validity Index

IT lecturers agree that the items are appropriate based on the study objectives and that the items are representatives of the important factors for students' computer self-efficacy. Figure 2 shows the lecturers rating on the content validity of each item. All the items are rated as "Strongly Agreed" and the content validity index (CVI) is 1.00 illustrated the high validity of the questionnaire. The designed instrument was face validated by 29 undergraduate computing students according to the validation criteria (Figure 3 ). All the items in the instrument were very relevant to the content of the study due to the reliability coefficient yielded an $r=0.755$ through Cronbach's alpha [12].

\begin{tabular}{|l|c|c|c|}
\hline \multicolumn{1}{|c|}{ Face Validation Criteria } & Mean & $\begin{array}{c}\text { Std. } \\
\text { deviation }\end{array}$ & $\mathbf{N}$ \\
\hline 1. The instruction is clear. & 4.52 & .574 & 29 \\
\hline $\begin{array}{l}\text { 2. The wording of the questions is } \\
\text { easy to understand. }\end{array}$ & 4.31 & .604 & 29 \\
\hline $\begin{array}{l}\text { 3. The flow of the questions is } \\
\text { easy to follow. }\end{array}$ & 4.52 & .634 & 29 \\
\hline $\begin{array}{l}\text { 4. The time taken to answer the } \\
\text { survey questions is reasonable. }\end{array}$ & 4.28 & .751 & 29 \\
\hline $\begin{array}{l}\text { 5. The meaning of every item is } \\
\text { clear. }\end{array}$ & 4.24 & .689 & 29 \\
\hline 6. The format is appropriate. & 4.31 & .660 & 29 \\
\hline 7. The font size is appropriate. & 4.76 & .435 & 29 \\
\hline
\end{tabular}

Figure 3. Face Validity

\section{F. Study Group and Data Collection}

Cluster sampling technique has been applied for data collection [16]. Cluster involves a group of participants, which represents the population, are identified and included in the sample. In this study, the cluster study groups are undergraduate students who are taking the Introduction to Information Technology course.

According to Roscoe [26], a sample size larger than 30 and less than 500 is most appropriate for researchers. For this study, 245 students participated in this data collection from five different programs (Agriculture, Business, Biotechnology, Computing and Medical Lab Technology), on the day class commenced. Data collection takes place in the academic year 2015, May semester. The participants are first semester students.

\section{Results and Discussion}

A computer self-efficacy questionnaire was employed to collect data. Students were asked to complete the questionnaire during the class time to secure a high response rate. Among the 245 questionnaires received, 128 respondents were identified from rural area based on their home address. Their profile is shown in Figure 4.

\begin{tabular}{|l|l|}
\hline Gender & $74(58 \%)$ \\
Male & $54(42 \%)$ \\
Female & $18>=$ and $<=40$ \\
\hline Age & $128(100 \%)$ \\
\hline Computer Experiences & $0(0 \%)$ \\
Yes & - Average Experiences = 7.5 years \\
No & - Minimum Experiences = less than 1 year \\
& \\
\hline
\end{tabular}

Figure 4. Participant Profile $(n=128)$

The levels of computer literacy have been categorized into four categories, namely poor, adequate and excellent. From the analysis, most of the students responded with "good" for their computer literacy level (Table 2).

Table 2. Level of Computer Literacy $(n=128)$

\begin{tabular}{|l|l|l|}
\hline Level & $\mathrm{n}$ & $\%$ \\
\hline Poor & 21 & 16.4 \\
\hline Adequate & 19 & 14.8 \\
\hline Good & 78 & 61.0 \\
\hline Excellent & 10 & 7.8 \\
\hline
\end{tabular}

As shown in Figure 5, only $4 \%(n=5)$ of the students had a low level of computer self-efficacy efficacy. The majority of the students, approximately $61 \% \quad(n=78)$, have high level of computer selfefficacy while the rest of the students had an average level of $35 \%$ $(n=45)$. 


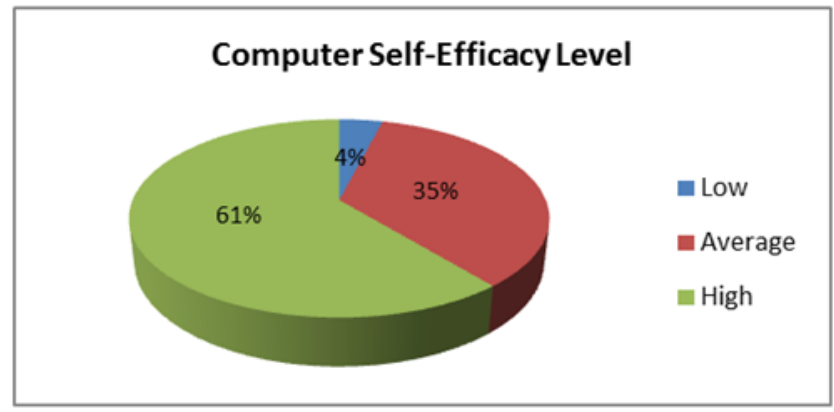

Figure 5. Level of Computer Self-Efficacy in Computer Skills $(n=128)$

Figure 6 shows basic and advanced computer self-efficacy levels. It can be said that the majority of students have high level of basic computer self-efficacy, which is $68 \%(\mathrm{n}=87)$ while $30 \%(\mathrm{n}=38)$ show average level and only $2 \%(\mathrm{n}=3)$ are low level. For advanced computer self-efficacy level, 55\% $(n=77)$ are high level, $40 \%(n=51)$ are average level and 5\% $(n=6)$ are low level.

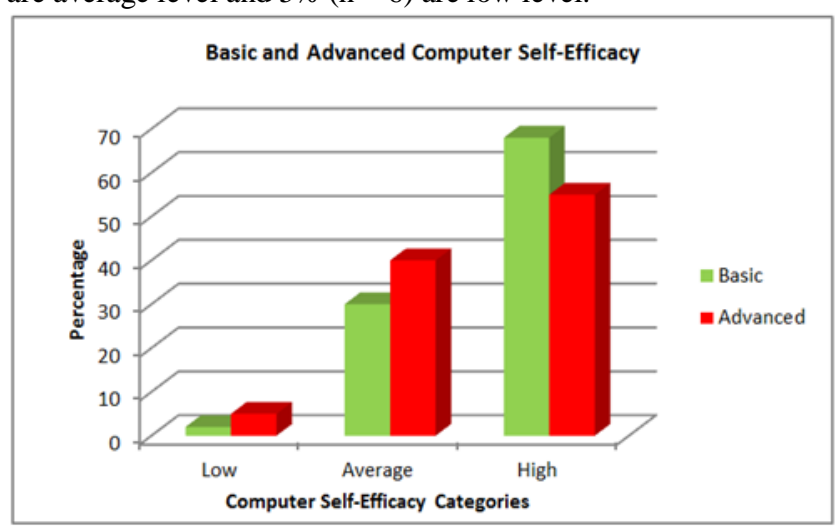

Figure 6. Level of Computer Self-Efficacy in Basic and Advanced Computer Skills $(\mathrm{n}=128)$

From the findings it can be said that students' confident level in computer skill is still below 50\%. Looking on the "Most Confident" column, the range of confident levels is $40 \%$ to $49 \%$ except there are a few computer skills which are below $40 \%$. The skills are from advanced level, listed in Figure 7.

\begin{tabular}{|l|c|c|}
\hline \multirow{2}{*}{$\begin{array}{c}\text { Computer Self-Efficacy } \\
\text { Question }\end{array}$} & \multicolumn{2}{c|}{$\begin{array}{c}\text { Absolutely } \\
\text { confident }\end{array}$} \\
\cline { 2 - 3 } & $\mathbf{n}$ & $\%$ \\
\hline Installing software correctly & 24 & 18.6 \\
\hline $\begin{array}{l}\text { I feel confident } \\
\text { troubleshooting computer } \\
\text { problems. }\end{array}$ & 20 & 15.6 \\
\hline $\begin{array}{l}\text { I feel confident } \\
\text { understanding terms/words } \\
\text { relating to computer } \\
\text { hardware. }\end{array}$ & 20 & 15.6 \\
\hline $\begin{array}{l}\text { I feel confident using the } \\
\text { computer to analyze } \\
\text { number data. }\end{array}$ & 20 & 15.6 \\
\hline $\begin{array}{l}\text { I feel confident learning } \\
\text { advanced skills within a } \\
\text { specific program } \\
\text { (software). }\end{array}$ & 21 & 16.4 \\
\hline
\end{tabular}

Figure 7. Computer Skills below $40 \%$

\section{Conclusion}

From the results, the rural area communities have adopted the ICT as part of their lifestyle. The results also provide several points and issues which need to be considered. Even though the computer selfefficacy of students from the rural areas is high, still some basic and advanced computer skills need to be improved. This is because most of the computer efficacies levels are only in the range of 40 to 49 in percentage.

Another concern is that students with high computer self-efficacy may not necessarily have competent skills as they believe they have. In order to confirm that students' beliefs match their actual skills, the second stage of this research will be a computer practical test. Computer self-efficacy ratings could then be compared to actual performance from the practical test.

In conclusion, even though the results show that the adoption of ICT by rural community has improved, the government still needs to enforce more ICT projects and strategies. Through this enforcement, ICT literacy among rural area communities can be achieved by the year 2020

\section{References}

[1] B. Abu Samah, M. Shaffril, H. Azril, and J.L.D.S. Alby, "Level of involvement in village administration and development activity among village development and security committee in village vision movement: an analysis of Malaysian case," European Journal of Scientific Research, vol.36, no.2, pp.308-317, 2009.

[2] P. Armum, and K. Chellappan, "Social and emotional self-efficacy of adolescents: measured and analysed interdependencies within and across academic achievement level," International Journal of Adolescence and Youth, pp.1-10, 2015.

[3] A. Bandura, "Social foundations of thought and action," The health psychology reader, vol.94, no.106, 2002.

[4] T. Busch, "Gender differences in self-efficacy and attitudes toward computers," Journal of Educational Computing Research, vol.12, no.2, pp.147-158, 1995.

[5] D.R. Compeau, and C.A. Higgins, "Computer self-efficacy: Development of a measure and initial test," MIS Quarterly, pp.189211, 1995.

[6] A. Durndell, Z. Haag, and H. Laithwaite, "Computer self-efficacy and gender: a cross cultural study of Scotland and Romania," Personality and individual differences, vol.28, no.6, pp.1037-1044, 2000.

[7] R. Embi, "Computer Anxiety and Computer Self-Efficacy among Accounting Educators at Universiti Teknologi MARA, Malaysia," (doctoral thesis). Virginia Polytechnic Institute and State University, 2007.

[8] N. Golafshani, "Understanding reliability and validity in qualitative research," The qualitative report, vol.8, no.4, pp.597-606, 2003.

[9] M.Z.B. Hasan, T.B. Hossain, and A. Islam, "Factors affecting selfefficacy towards academic performance: a study on Polytechnic students in Malaysia," Advances in Environmental Biology, pp. 695706, 2014

[10] M.A. Hassan, B.A. Samah, H.M. Shaffril, and J.L. D'Silva, "Perceived usefulness of ICT usage among JKKK members in Peninsular Malaysia," Asian Social Science, vol.7, no.10, pp.255, 2011.

[11] M. Hazura M.J. Hairulliza, F.M.N. Siti and M.Y. Zawiyah "Bridging Digital Divide: A Study on ICT Literacy among Students in Malaysian Rural Areas," Australian Journal of Basic and Applied Sciences, vol.6, no.7, pp.39:45, 2012. ISSN 1991-8178

[12] M.A. Hertzog, "Considerations in determining sample size for pilot studies," Research in Nursing \& Health, vol.31, no.2, pp.180-191, 2008.

[13] T. Hill, N.D. Smith, and M.F. Mann, "Role of efficacy expectations in predicting the decision to use advanced technologies: The case of computers," Journal of Applied Psychology, vol.72, no.2, pp.307, 1987.

[14] N. Ibrahim "Rural Development in Malaysia. UTM Johor: Centre for Innovative Planning and Development," Monograph 4, 2010. 
[15] J.B. Iis, and A.W.B.Z. Abidin, "Digital Inequalities Between The Rural And Urban Students," Malaysia. International Journal of Business and Social Science, vol.2, no.12, 2011.

[16] S.L. Jackson, "Research methods and statistics: A critical thinking approach. Cengage Learning, 2015.

[17] H.M. Judi, H.M. Amin, N.A.M. Zin, and R. Latih, "Rural students' skills and attitudes towards information and communication technology," Journal of Social Sciences, vol.7, no.4, pp.619, 2011.

[18] K. Kamaruddin, "Adult Computer Literacy Programme in Rural Areas in Peninsular Malaysia," The Journal of Human Resource and Adult Learning, vol. 4, no.2, 2008.

[19] M.B. Kinzie, and M.A. Delcourt, "Computer technologies in teacher education: The measurement of attitudes and self-efficacy," 1991.

[20] R. Mahyuddin, H. Elias, L.S. Cheong, M.F. Muhamad, N. Noordin, and M.C. Abdullah, "The relationship between students' self-efficacy and their English language achievement," Jurnal Pendidik dan Pendidikan, vol.21, pp.61-71, 2006.

[21] I.T. Miura, I. T. "The relationship of computer self-efficacy expectations to computer interest and course enrollment in college," Sex Roles, vol.16, no.5-6, pp.303-311, 1987.

[22] C.A. Murphy, D. Coover, and S.V. Owen, "Development and validation of the computer self-efficacy scale," Educational and Psychological Measurement, vol.49, no.4, pp.893-899, 1989.

[23] A.H. Musa, "Benefiting ICT for all. Inaugural Lecture Series," Serdang: UPM Publisher, 2008.

[24] S.S. Noor Sharifah, "Model planning on traditional village in Peninsular Malaysia," Rural Planning Center, Faculty of AlamBina, UTM. Skudai, Johor: Technology University of Malaysia Publisher, 2003.

[25] K. Rex, and R.M. Roth, "The relationship of computer experience and computer self-efficacy to performance in introductory computer literacy courses," Journal of Research on Computing in Education, vol.31, no.1, pp.14-24, 1998.

[26] J.T. Roscoe, "Fundamental research statistics for the behavioral sciences," New York, NY: Holt, Rinehart and Winston, 1975.

[27] H.K. Sam, A.E.A. Othman, and Z.S. Nordin, "Computer self-efficacy, computer anxiety, and attitudes toward the Internet: A study among undergraduates in Unimas. Educational Technology \& Society, vol.8, no.4, pp.205-219, 2005.

[28] S.F. Samsuddin, J. Bolong, S.Z. Omar, J.L. D'Silva, H. Sahharon, and H.A.M. Shaffril, "Examining the impact of demographic factors on the attitude of rural communities in Malaysia towards village WiFi services," Asian Social Science, vol.11, no.18, pp.134, 2015.

[29] S.S.M. Sawari, M.A.I. Ghazali, F.A. Trayek, and M.Z.A. Mat, "Examining learning and peer efficacy among secondary school students in district of ledang," UMRAN-International Journal of Islamic and Civilizational Studies, 2016. (EISSN: 2289-8204), 3(2).

[30] G. Torkzadeh, and X. Koufteros, "Factorial validity of a computer self-efficacy scale and the impact of computer training," Educational and Psychological Measurement, vol.54, pp.813-813, 1994. 